\title{
Fecal Flora and Cecal Weights in Mice Given Validamycin A
}

\author{
Akihiro IMAI \\ Biological Research Laboratories, Central Research Division, \\ Takeda Chemical Industries, Ltd., \\ Juso-nishinocho, Higashiyodogawa-ku, Osaka
}

(Received for publication: April 3, 1974)

\begin{abstract}
Validamycin A (validamycin A 81\%) and penicillin G were administered to 4-weekold male mice for 14 to 15 days. Mice were given ad libitum drinking water containing $50 \mathrm{~g} / 1$ of validamycin $\mathrm{A}$ or $0.3 \mathrm{~g} / 1$ of penicillin $\mathrm{G}$. The mean dosages of validamycin $\mathrm{A}$ and penicillin $\mathrm{G}$ were calculated from water intake as $400 \mathrm{mg} / \mathrm{mouse} /$ day and 2.4 $\mathrm{mg} / \mathrm{mouse} /$ day, respectively. (1) No difference was seen in the body-weight gain and water intake between control and each treated group. No abnormality was recognized in the behaviour or appearance of the mice, except for the excretion of soft feces from the mice treated with either antibiotics. (2) No difference was seen in the fecal microflora between control and validamycin A-treated groups. However, the numbers of microorganisms in the feces of mice treated with penicillin $G$ were descreased on the first day of treatment. Thereafter, bacteroides and lactobacilli were disappeared,
\end{abstract} while the numbers of Enterobacteriaceae and streptococci were markedly increased.

(3) The wet weight of the cecum of mice treated with validamycin A and penicillin $\mathrm{G}$ was significantly increased on the first to the 15 th day of treatment. The dry weight of the cecum with contents was not different from that of control mice. The increased wet weight of the cecum of the treated mice was largely accounted for the rise of water contents. (4) In mice treated with validamycin A and penicillin G, histological observation of the cecum did not indicated any significant abnormality of the mucosal layer, lamina propria and submucosal layer, although some partial relaxation of the inner circular muscle was observed. Histo-bacteriological examination showed a colonization of Gram-positive and Gram-negative bacteria in the lamina propria and submucosal layer of the cecum of the mice treated with both antibiotics. However, the numbers of Gram-negative tapered rods-fusiform bacteria-were decreased and disappeared in validamycin A-treated mice and in penicillin G-treated mice, respectively. (5) It is presumed that the swelling and enlargement of the cecum in mice treated with validamycin A was caused by the reduced population of fusiform bacteria in the same fashion as demonstrated in the case of penicillin G.-Experimental Aninals 23 (4) 215-224, 1974.

\section{Introduction}

Validamycin A isolated from the culture of of Streptomyces hygroscopicus var. limoneus nov. var. T-7545 has been shown to be effective for the control of Rhizoctonia disease such as sheath blight of rice plant caused by Pellicularia sasakii and damping off and southern blight of vegetables [4]. On the other hand, it has been reported that validamycin $\mathrm{A}$ has no in vitro activity against bacteria, yeasts and fungi except Corticium spp. [3] and that, when orally administered, the drug showed no significant toxicity to mice and rats, except the enlargement of the cecum in these animals [6].

In the present studies, the enlargement of 
the cecum in mice induced by daily oral administration of validamycin $\mathrm{A}$ was investigated more precisely by bacteriological and histological examination in comparison with the enlargement of the cecum observed in the penicillin Gtreated mice.

\section{Material and Methods}

Mice: Four-week-old male ddY-SLC mice (SPF) weighing 20 to $21 \mathrm{~g}$ were used in this experiments. These mice were housed in groups of 3 or 9 mice in a metal cage with wood shavings for bedding and given commercial CA-1 pellets (Japan CLEA) and water ad libitum. Wood shavings, cages, pellets and water were used without sterilization. Wood shavings were changed twice a week. During this experiments, the room temperature and humidity were maintained in the range of $23 \pm 1^{\circ} \mathrm{C}$ and $55 \pm 5 \%$, respectively. The weight of the mice in each experimental group of 3 per cage was recorded every morning.

Antibiotics: In this experiments, mice were given the drinking water containing $50 \mathrm{~g}$ of validamycin A (validamycin A $81 \%$. Takeda Chemical Ind. Ltd.) or $0.3 \mathrm{~g}$ of penicillin $\mathrm{G}$ (Takeda Chemical Ind. Ltd.) per liter ad libitum for 14 or 15 days, respectively. The water intake of 3 mice in each group were measured every morning so as to calculate the actual doses of both antibiotics. The mean daily water intake was 7 to $8 \mathrm{ml} /$ mouse in the present experiment.

Quantitative enumeration of fecal bacterial flora: At various intervals of the feeding period, 2 or 3 fresh fecal pellets were obtained from the anus of each mouse and homogenized in 100 parts of sterile diluent. The diluent was prepared by mixing $1 \mathrm{~g}$ of Norit A (American Norit Co.) in 1 liter of distilled water, filtering and autoclaving [5]. Ten-fold serial dilutions of the homogenates were prepared and $0.1 \mathrm{~m} l$ of the appropriate dilution was spread on the surface of various selective agar media cited below and then these plates were incubated at $37^{\circ} \mathrm{C}$. Enterobacteriaceae was incubated aerobically on Mac Conkey agar for 24 hours, staphylococci aerobically on mannitol salt agar for 48 hours, streptococci aerobically on azide blood agar for 48 hours and yeast aerobically on potato dextrose agar for 48 hours. Clostridia, bacteroides and lactobacilli were incubated anaerobically by steel wool method [1], on NN, NBGT and synthetic media [9] for 72 hours, respectively. Termination of the respective incubations was followed by counting of the colonies on the agar plate for the calculation of the microorganisms in $0.1 \mathrm{~g}$ of the feces.

Examination of the cecum: At various intervals of the feeding period, mice were sacrificed by ether anesthesia and the cecum with contents were weighed immediately after excising and again after drying at $37^{\circ} \mathrm{C}$ for 2 days. Some of the cecum after removing the contents by washing with pysiological saline were opened longtitudinally for the immediate fixation in Bouin solution. Specimens were embedded in paraffln, sectioned at $5 \mu \mathrm{m}$. The sections were stained-with hematoxylin-eosin or Gram stain for histological and bacteriological examinations.

\section{Results}

Effects of drugs on body weight gain and water intake: Though the mice treated with validamycin $A$ or penicillin $G$ evacuated the soft feces after the second day of administration, no significant difference in body weight gain was demonstrated between the control and treated mice (Fig. 1). The daily water intake

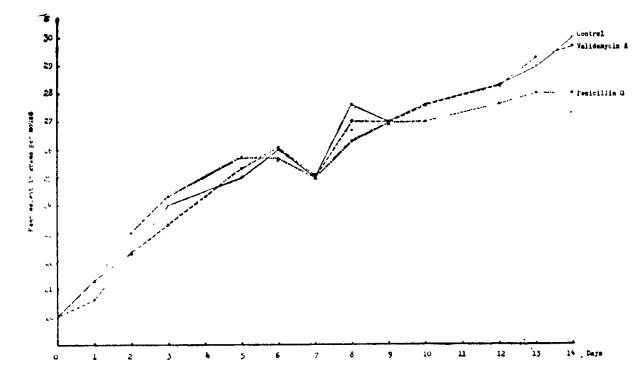

Fig. 1. Changes of Body weights After Drug Administration The figures indicate the mean weight of 3 mice.

varied considerably, but the total amounts of drinking water consumed during the entire feeding period were nearly of the same amount in the control and treated mice (Fig. 2). The

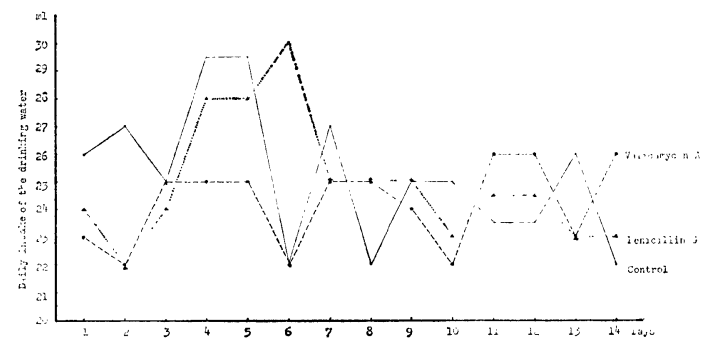

Fig. 2. Changes of Daily Intake of the Drinking Water Containing Validamycin $A$ or Penicillin G. The figures indicate the mean intake of 3 mice.

mean of daily intake of the test materials was calculated as $400 \mathrm{mg}$ of validamycin $\mathrm{A}$ or 2.4 $\mathrm{mg}$ of penicillin $\mathrm{G}$ per mouse. 
Effects on fecal bacterial flora: Enterobacteriaceae and staphylococci in the feces sampled from the control mice varied considerably in number during the experimental periods, while the numbers of streptococci, bacteroides and lactobacilli were relatively uniform (Fig. 3).

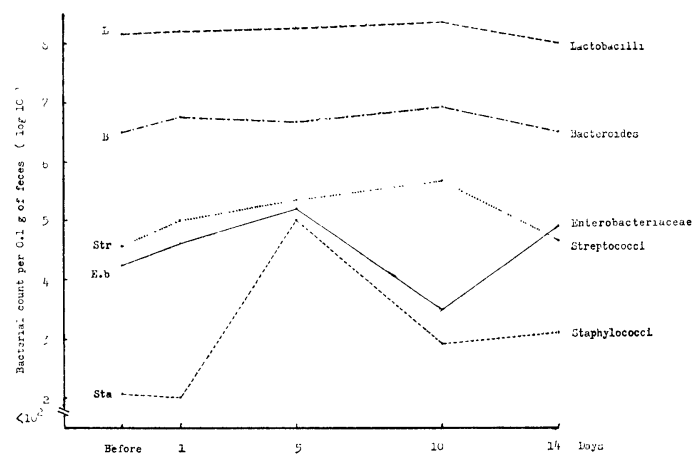

Fig. 3. Changes of Fecal Flora: Control The figures indicate the mean numbers of 3 mice.

Staphylococci in the feces sampled from the mice treated with penicillin $G$ was stable in number during the experimental periods. On the other hand, a marked decrease in number of bacteroides and lactobaccilli observed on the first day of treatment was followed by an almost complete disappearance. Enterobacteriaceae and streptococci were decreased in number on the first day, but the numbers on the 5 th day were superior to the initial level. Most of Enterobacteriacease found in the mice treated with penicillin $\mathrm{G}$ were classified into Klebsiella. Aeroba:ter types (Fig. 4).

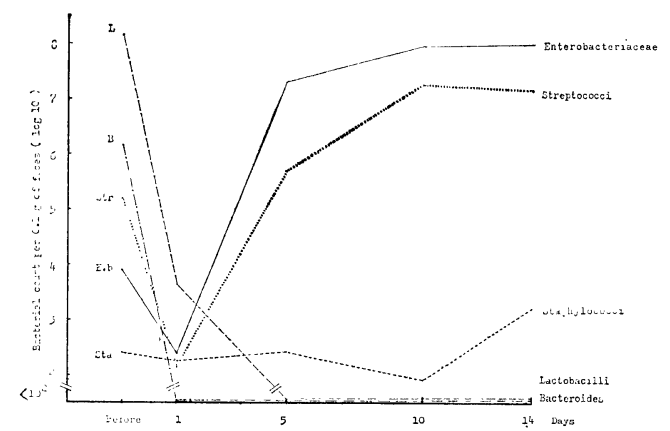

Fig. 4. Changes of Fecal Flora: Penicillin G. The figures indicate the mean numbers of 3 mice.
Treatment of the mice with validamycin A resulted in the decrease in number of E. coli, Paracolobacterum and Proteus but in the increase in number of Enterobacteriaceae including Klebsiella-Aerobatter types in the feces. Staphylococci were increased in number on the first to the 10th day and reduced to the previous population on the 14th day. The number of bacteroides was increased by 5 -day-feeding and thereafter their level was found to be constant until termination of the feeding period. Lactobacilli slightly reduced in number on the first day were found to be maintained until termination of the feeding period (Fig. 5).

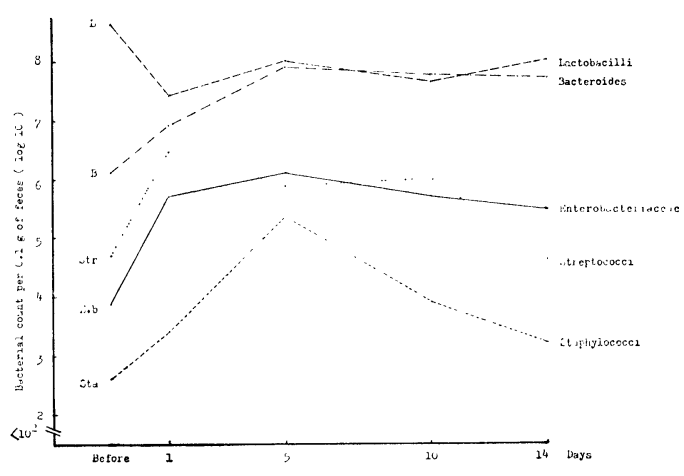

Fig. 5. Changes of Fecal Flora: Validamycin A The figures indicate the mean numbers of 3 mice.

Furthermore, clostridia and yeast could not be detected in the feces of control and both drug-treated mice throughout feeding periods.

Effects on the weight of the cecum: The wet weight of the cecum increased in association with the body weight gain in the control mice, 1.5 to $1.6 \%$ of the body weight. The weight of the cecum was doubled by treatment with penicillin $G$ on the first day and thereafter it was further increased gradually. The treatment of the mice with validamycin A resulted in a marked and prompt increase in wet weight of the cecum on the first day. The cecal weight reached to the trippled value on the 5 th day, and then showed a slight declination (Table 1). On the other hand, the dry weight 


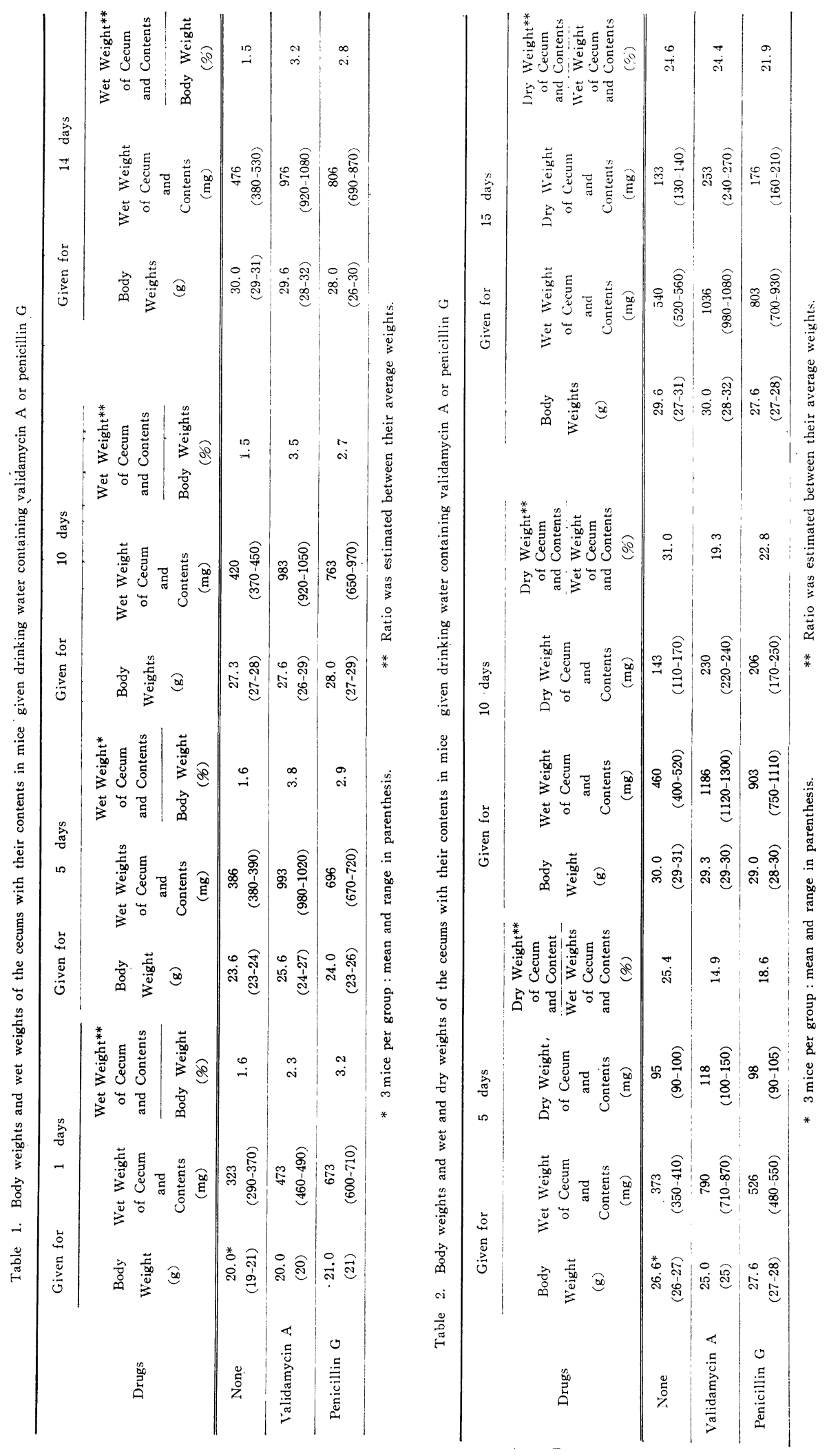




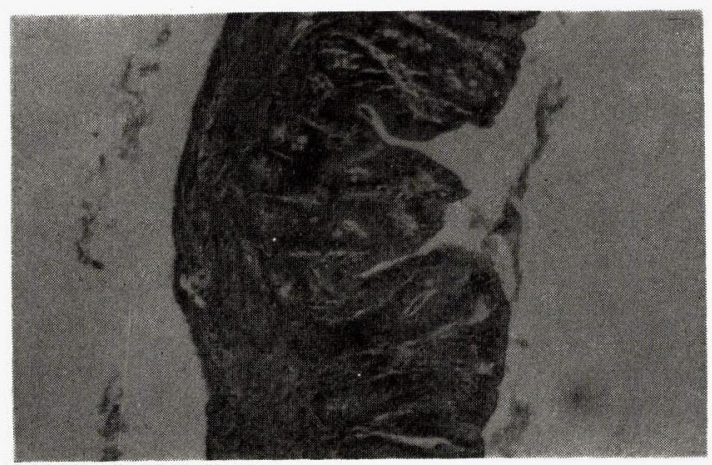

Fig. 6 : Hematoxylin-eosin stained histological section of the cecum of a control mouse at the 14 th day.

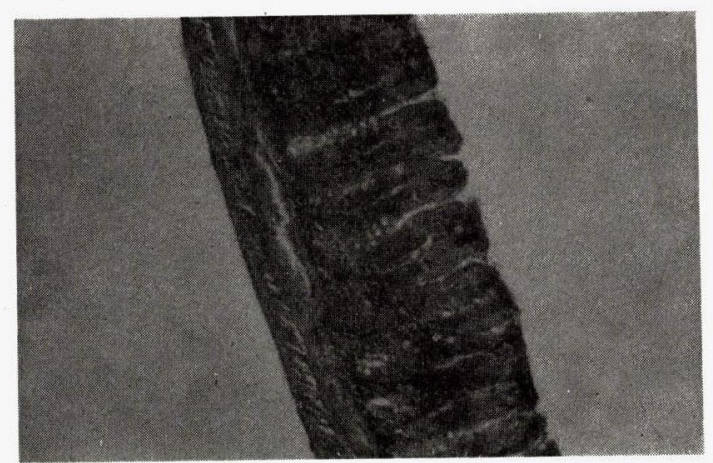

Fig. 8: Hematoxylin-eosin stained histological scction of the cecum of a mouse given the drinking water containing validamycin A at the 14 th day. Sections show that the inner circulatory muscle of the cecum in mice given penicillin $G$ or validamycin A were somewhat thin as compared with that of a control mouse and that no cellular reactions were present in mucus layer of the cecum removed from control and both drug-treated mice.

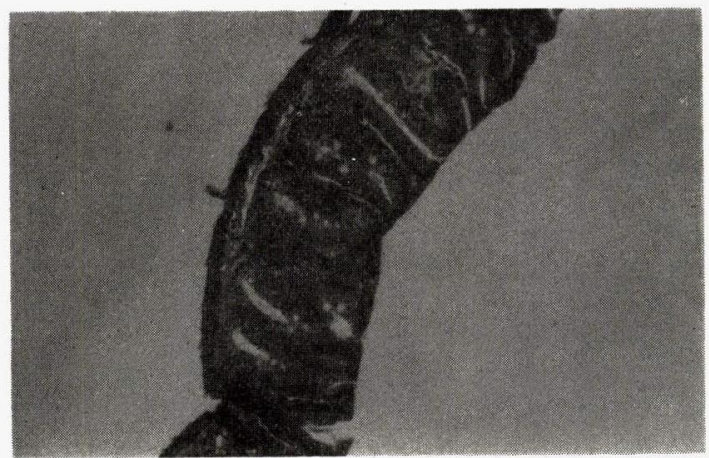

Fig. 7 : Hematoxylin-eosin stained histological section of the cecum of a mouse given the drinking water containing penicillin $G$ at the 14 th day.

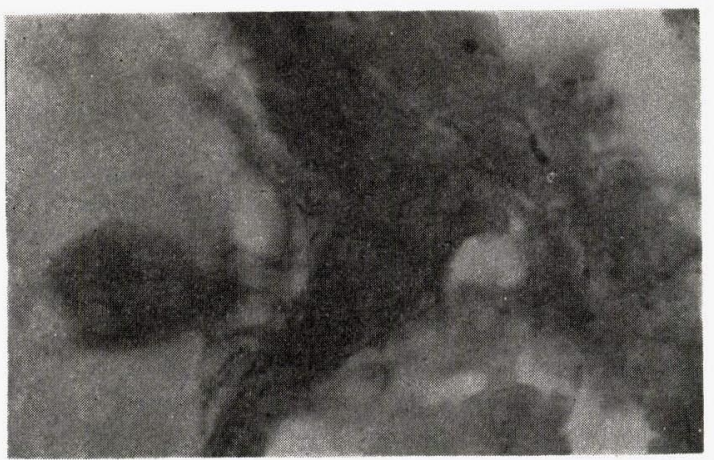

Fig. 9: Gram stained histological section of the cecum of a control mouse. Section shows that mixed microbial population, especially Gram-negative tapered rods-fusiform bacteria-were populated in the crypts.

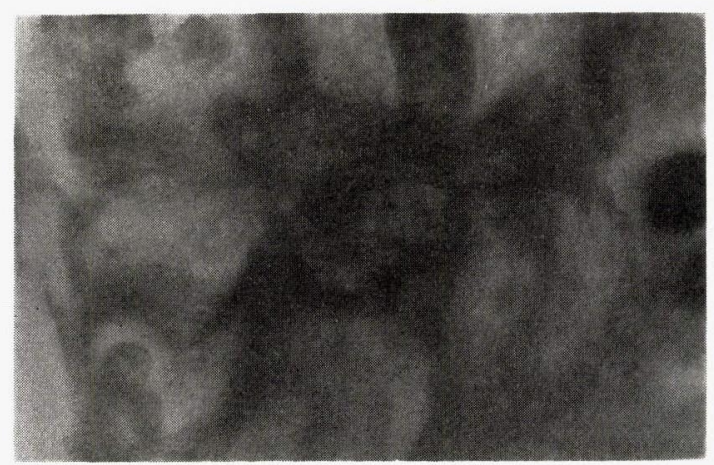

Fig. 10: Gram stained histological section of the cecum of a control mouse. Section shows that a small population of Gram-positive and Gram-negative bacteria were present in the lumen. 


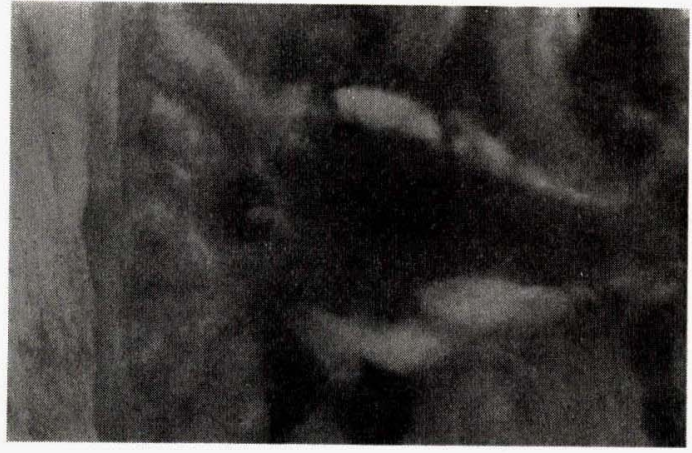

Fig. 11: Gram stained histological section of the cecum of a control mouse. Section shows that a large population of Gram-positive and Gram-negative bacteria present in the lumen, but that these bacteria were not recognized at site close to the muscularis mucosae.

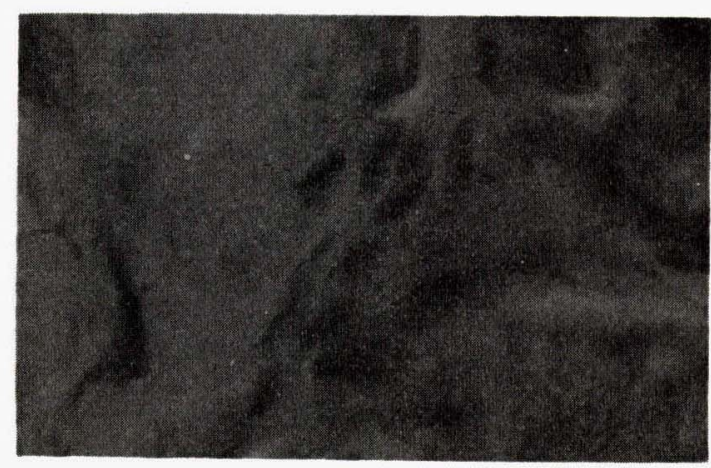

Fig. 13: Gram stained histological section of the cecum of a mouse given the drinking water containing penicillin $G$ at the 5 th day. Section shows that Gram-positive and Gram-negative bacteria were localized at the site close to the muscularis mucosae.

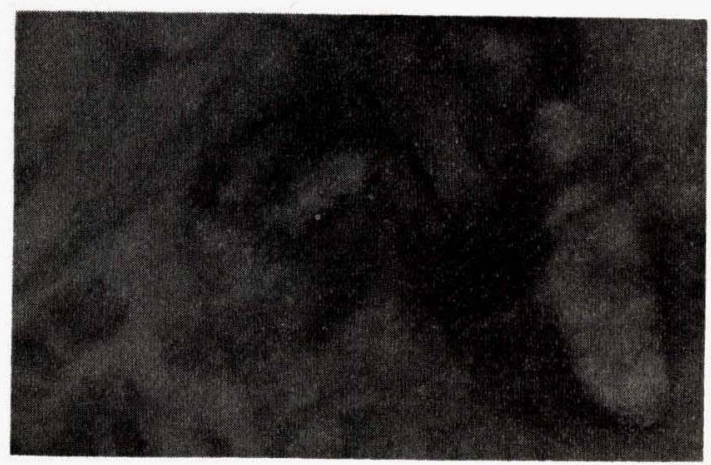

Fig. 15: Gram stained histological section of the cecum of a mouse given the drinking water containing validamycin $\mathrm{A}$ at the 5 th day. Section shows that some of fusiform bacteria in the lumen entered into the cytoplasma of epithelial cells.

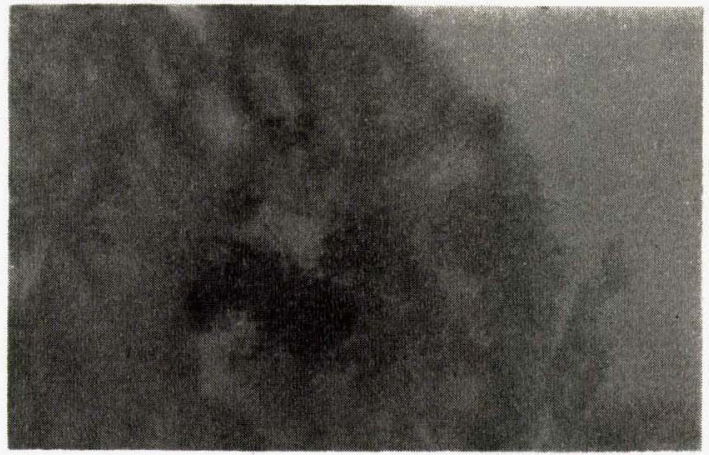

liig. 12 : Gram stained histological section of the cecum of a mouse given the drinking water containing penicillin $G$ at the first day. Section shows that all most bacteria, especially fusiform bacteria disappeared from the mucosal surface and that Grampositive and Gram-negative bacteria colonized in the lumen and the lamina propria.

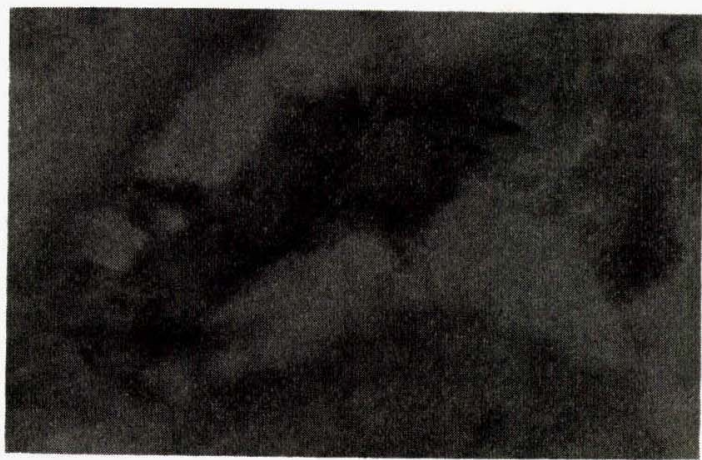

Fig. 14: Gram stained histological section of the cecum of a mouse given the drinking water containing varidamycin $A$ at the first day. Section shows that mixed microbial population were present in the lumen and the mucosal surface and that Gramnegative tapere drods - fusiform bacteria - in the crypt were elongated and their numbers were decreased.

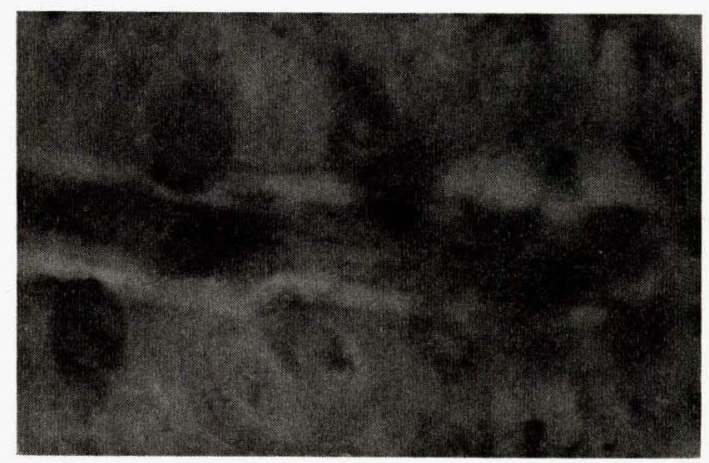

Fig. 16: Gram stained histological section of the cecum of a mouse given the drinking water containing validamycin $\mathrm{A}$ at the 10 th day. Section shows that fusiform bacteria in the lumen tended to be undistinguished the contour of the cell body and consequently to be recognized only the Gram-positive granules. 
of the cecum of mice treated with validamycin A or penicillin $G$ was increased slightly, but the increase ratio was far less than that in the wet weight (Table 2). Therefore, the increase of wet weight was due largely to an increase in the amount of water in the cecum and contents.

Histological findings of the cecum: The mucosal layer, lamina propria, and submucosal layer of the cecum of the mice treated with validamycin $A$ or penicillin $G$ showed no abnormality. The inner circulatory muscle, however, were somewhat thin (Fig. 6, 7, 8).

In the control mice, Gram-positive and Gramnegative bacteria were abundant in the crypts and the lumen and a few of them was scattered in the lamina propria and submucosa (Fig. 9, 10, 11) . Especially, large population of Gram-negative tapered rods-fusiform bacteriapopulated in the crypts (Fig. 9). Though microorganisms on the mucosal surface were almost disappeared already on the first day of treatment with penicillin $\mathrm{G}$, a large number of Gram-positive and Gram-negative bacteria were colonized in the lumen, the lamina propria and the submucosa (Fig. 12). Fusiform bacteria tended to be recognized only in Gram-positive granulus with disappearance of cell walls and consequently, these bacteria could not be seen in histological sections. After the 5th day, the Gram-positive and Gram-negative bacteria were localized as a colonization at the site close to the muscularis mucosae and some of them were found in the cytoplasma of mucosal epithels (Fig. 13). As indicated by culture results, many of the Gram-positive and Gram-negative bacteria were present in the lumen and the crypts in the sections of the cecum removed from the mice treated with validamycin $A$. However, Gram-negative tapered rods-fusiform bacteria-present on the mucosal surface and in the lumen of the cecum showed some swelling and elongation (Fig. 14, 15), and some of them entered into the cytoplasma of the epithelial cells (Fig. 15). At the late period of the feeding, these bacteria were decreased in number as being grouped in the lumen, the lamina propria and the submucosa. Such change was associated with undistinguished contour of the cell body and existence of the Gram-positive granules (Fig. 16).

\section{Discussion}

Antibacterial drugs added to the drinking water induced markedly qualitative and quantitative changes in fecal flora, the enlargement of the cecum and the evaculation of the soft feces in mice [7, 8]. In the beagle dogs the treatment with large doses of validamycin A induced an evacuation of the soft feces without exhibiting significant cecal enlargement and changes of the fecal flora [2]. However, the enlargement of the cecum and the evacuation of the soft feces in the mice by treatment with validamycin A were also confirmed in the present experiments. The increase in weight of the cecum with its contents was largely ascribed to an increase in water content in the cecum. The enlarged cecum showed a peak increase in weight already on the 5 th day of treatment with free access to drinking water containing $50 \mathrm{~g} / 1$ of validamycin A. The mice treated with validamycin A showed an enlarged cecum with some relaxation of the circulatory muscles, and a significant decrease in number of fusiform bacteria associated with colonization of Gam-positive and Gramnegative bacteria on mucus layers of the cecal wall as well as the case of the mice treated with penicillin G. It was reported that the enlargement of the cecum in mice treated with various kinds of antibiotics, such as penicillin, tetracyclin and kanamycin, are concomitant with the elimination of certain types of bacteria, especially fusiform bacter!a $[7,8]$. The enlargement of the cecum of mice treated with validamycin A are largely considered to be induced in the same fashion as that of the mice 
treated with penicillin G, but may be partially due to some pharmacological effects of validamycin $\mathrm{A}$ on activities of intestinal tracts. The biological significance of such changes of the fecal flora and cecum size caused by these antibiotics awaits further studies.

In regard to changes of intestinal flora of mice after administration of penicillin in histological examinations, Savage et al. [7] have reported the decrease in number of intestinal flora, especially fusiform bacteria, in the lumen and the mucosal epithelium of the cecum, but have not described about changes of intestinal flora in the other areas of the cecum. However, in this experiments, the formation of colonization of Gram-positive and Gram-negative bacteria were recognized in the lumen, the lamina propria, the submucosa and at the site close to the muscularis mucosal, except the decrease in number of fusiform bacteria after administration of both antibiotics. Such formation of colonization of bacteria may be considered to be attributed to the protective reactions of bacteria against antibiotics or to changes of some mechanisms (absorption or metabolism or others) of the cecal mucosa after administration of antibiotics, in order to survive or grow at the sites that these bacteria are not influenced by bactericidal effects of antibiotics. Accordingly, sites of colonization of bacteria after administration of antibiotics may be considered to be different depending on types or kinds of antibiotics. Furthermore, although such colonization of bacteria were observed, no cellular reactions were recognized in these areas. On the other hand, it was reported that a greater population of inflammatory cells were seen in lamina propria of adult germ-free mice contaminated with cecal homogenates from normal mice. [10]. The factt hat such cellular reactions were not recognized in this experiments may be considered to be attributed to results that mucus layers and epithelial cells of the cecum have continously stimulated by indigenous intestinal bacteria and their products after birth. However, the formation of colonization of Grampositive and Gram-negative bacteria in the lumen, the lamina propria, the submucosa and at the site close to the muscularis mucosal of the cecum and no cellular reactions in these areas in mice after administration of antibiotics should be need to further examinations.

\section{References}

[1] Azuma, R., Ogimoto, K. and Suto, T. (1962). Anaerobic culture method with steel wool. Japan. J. Bact., 17, 802-806.

[2] Hosokawa, S., Ogiwara, S. end Murata, Y. (1974). Oral subacute toxicity of validamycin A in beagle dogs for 4 months. (in press).

[3] Iwasa, T., Higashide, E., Yamamoto, H. and Shibata, M. (1971). Studies on validamycins, new antibiotics. II. Production and biological properties of validamycin A and B. J. Antibiotics., 24, 107-113.

[4] Iwasa, T., Yamamoto, H. and Shibata, M. (1970). Studies on validamycin, new antibiotics. I. Streptomyces hygroscopicus var. limoneus not. var. validamycin-producing organism. Ibid., 23, 595-602.

[5] Lavison, M. E. and Kaye, D. (1969). Fecal flora in man. Effect of cathartic. J. Inf. Dis., 119, 591-596.

[6] Onishi, S. (1973). On the effect of validamycin in rats and mice. Med. J. Osaka Univ., $23,215-227$.

[7] Savage, D. C. and McAllister, J. S. (1971). Cecal enlargement and microbial flora in suckling mice given antibacterial drugs. Inf. and Imm., 3, 342-349.

[8] Savage, D. C. and Dubos, R. (1968). Alterations in the mouse cecum and its flora produced by antibacterial drugs. J. Exp. Med., 128, 97-110.

[9] Schaedler, R. W. and Dubos, R. (1967). The fecal flora of various strains of mice. Its bearing on their susceptibility to endotoxin. J. Exp. Med., 115, 1149-1159.

[10] Syed, S. A., Abrams, G. D. and Freter, R. (1970). Efficiency of various intestinal bacteria in assuming normal functions of enteric flora after association with germ-free mice. Inf. and Imm., 2, 376-386. 


\title{
Validamycim A 投与マウスにおける \\ 粪便菌叢及び盲腸重量の変化について
}

\author{
今, 非旁浩 \\ 武田薬品工業株式会社 \\ 中央研究所生物研究所
}

validamycin A および penicillin $\mathrm{G}$ をそれぞれ $50 \mathrm{~g}$ $/ 1 \ell$ および $0.3 \mathrm{~g} / \ell$ の濃度に水道水にとかし給水瓶に入 れ，自由飲水によりマウス（ddy-SLC. 4 W. 占. 20 $21 \mathrm{~g} ）$ に 14〜15日間投与した。その間, 飲水量および体 重を測定し, 同時に経時的に糞便菌叢の変化, 盲腸重量 （内容を含む）の変化および盲腸の組織学的検索を行っ た。

(1) マウス 1 匹あたりの 1 日間の平均薬剤摄取量は validamycin A 約 $400 \mathrm{mg}$, penicillin G 約 $2.4 \mathrm{mg}$ であ った。両薬剤とも, 投与により軟便を認めたが, 飲水量, 体重増加など特に異常は認められなかった。

(2) validamycin A 投与により培養可能な粪便菌叢 には変化はみられなかった。 penicillin G 投与では, 投与 1 日後に全菌数が減少し，その後， bacteroides， lactoaacilli は消失したが, Enterobacteriaceae, streptococci は急激に増加した。

（3）盲腸の湿潤重量（内容を含む）は両薬剂投与によ
り, 投与 1 日後より急激に増加し, 実験終了時まで持続 した。しかし, 乾燥重量 (内容を含む) は殆んど増加し ないので, 湿潤重量の増加は水分の増加によるあのであ った。

（4）盲腸の組織学的検査では, 両薬剤投与群とも全例, 粘膜固有層には著変は認められなかったが, 内輪走筋に 部分的菲薄化が認められた。

また, 組織細菌学的検査では, 両薬剂投与マウスとあ, Gram 陽性菌, 陰性菌の粘膜下織, 筋層への集合が認め られた。ただし, Gram-ngative tapered rods-fusiform bacteria は validamycin A 投与マウスでは減少し， penicillin $\mathrm{G}$ 投与マウスでは検出できなかった。

（5）マウスに validamycin A を投与した場合の盲腸 膨大は penicillin G についていわれていると同じよう に, 腸内細菌叢の変化, 特に fusiform bacteria の減少 によるあのと考える。 